\title{
MODEL PELIMPAHAN KEWENANGAN BADAN PEMERIKSA KEUANGAN DALAM PELAKSANAAN TUGAS PEMERIKSAAN PENGELOLAAN DAN TANGGUNG KEUANGAN NEGARA
}

\author{
Muhammad Ramadhani ${ }^{1}$, Bahrullah Akbar ${ }^{2}$, Murtir Jeddawi ${ }^{3}$, M. Irwan Tahir ${ }^{4}$ \\ Institut Pemerintahan Dalam Negeri (IPDN) \\ Email: muhammad.ramadhani@bpk.go.id
}

\begin{abstract}
Abstrak
Penelitian ini bertujuan untuk menganalisis permasalahan bagaimana pelimpahan kewenangan dan model pelimpahan kewenangan yang dapat dikembangkan bagi BPK dalam pelaksanaan tugas pemeriksaan pengelolaan dan tanggung jawab keuangan negara menggunakan teori dari Koontz dan Weihrich mengenai tujuh prinsip untuk melakukan pelimpahan kewenangan. Metode penelitian yang digunakan yaitu desain penelitian kualitatif dengan pendekatan deskriptif. Hasil penelitian menunjukkan bahwa mekanisme pelimpahan belum sepenuhnya selaras dengan Undang-Undang Nomor 30 Tahun 2014 tentang Administrasi Pemerintahan. Hambatan dalam implementasi kebijakan pelimpahan kewenangan adalah desain kebijakan belum selaras dengan regulasi yang berlaku, dan perlu komitmen dari pembuat kebijakan dan pelaksana kebijakan untuk menyesuaikan kebijakan dan implementasi kebijakan dengan perkembangan peraturan perundang-undangan dan asasasas umum pemerintahan yang baik. Model pelimpahan kewenangan yang disarankan penelitian ini dalam pelaksanaan tugas pemeriksaan pengelolaan dan tanggung jawab keuangan negara adalah mandat tugas pemeriksaan secara komprehensif, sehingga pelaksana BPK, dan tenaga pemeriksa dan tenaga ahli di luar BPK melakukan tugas pemeriksaan untuk dan atas nama BPK berdasarkan peraturan perundang-undangan dan asas-asas umum pemerintahan yang baik.
\end{abstract}

Kata Kunci: Pelimpahan Kewenangan, Pemeriksaan Keuangan Negara, Badan Pemeriksa Keuangan.

\section{Abstract}

This study aims to analyze the problem of how the delegation of authority and the model of delegation of authority that can be developed for the BPK in the implementation of auditing tasks for the management and responsibility of state finances using Koontz and Weihrich's theory regarding the seven principles for transferring authority. The research method used is a qualitative research design with a descriptive approach. The results showed that the transfer mechanism was not fully in line with Law Number 30 of 2014 concerning Government Administration. The obstacle in the implementation of the delegation of authority policy is that the policy design is not in line with the applicable regulations, and it requires commitment from policy makers and policy implementers to adjust policies and policy implementation with the development of laws and regulations and general principles of good governance. The model of delegation of authority suggested by this study in the implementation of auditing tasks for the management and responsibility of state finances is a comprehensive audit task mandate, so that the BPK executor, and examiners and experts outside the BPK perform audit duties for and on behalf of the BPK based on statutory regulations and general principles of good governance.

Keywords: Delegation of Authority, State Financial Audit, Supreme Audit Agency. 


\section{A. PENDAHULUAN}

Semenjak perubahan ketiga Undang-Undang Dasar Negara Republik Indonesia Tahun 1945 (UUD 1945), pengaturan tugas dan kewenangan Badan Pemeriksa Keuangan (BPK) sebagai satu-satunya lembaga negara yang melakukan pemeriksaan pengelolaan dan tanggung jawab keuangan negara telah diatur dalam bab tersendiri pada UUD 1945, yaitu dalam Bab VIIIA Pasal 23E sampai dengan Pasal 23G. Tugas dan kewenangan BPK yang telah diperkuat dengan perubahan UUD 1945 tersebut di antaranya terlihat dari fungsi BPK yang menurut Moh. Kusnardi dan Bintan R. Saragih (1994, hlm. 88) terdapat tiga hal, yaitu: 1) fungsi operatif, dengan melakukan pemeriksaan, pengawasan, dan penulisan atas penguasaan, dan pengurusan keuangan negara; 2) fungsi yudikatif, dengan melakukan tuntutan perbendaharaan dan tuntutan ganti rugi terhadap bendaharawan yang karena perbuatannya melanggar hukum atau melalaikan kewajibannya, menimbulkan kerugian bagi negara; dan 3) fungsi rekomendatif, dengan memberi pertimbangan kepada pemerintah tentang pengurusan keuangan negara.

Tugas BPK berbasis kepada kewenangannya yang bersifat atributif sesuai dengan UUD 1945 sebagai lembaga negara yang memiliki tugas melakukan pemeriksaan terhadap pengelolaan dan tanggung jawab keuangan negara yang dijalankan oleh seluruh instansi atau institusi yang mengelola keuangan negara (Mulya \& Rani, 2018). Dengan demikian, BPK sesungguhnya dapat diartikan sebagai lembaga negara yang melakukan pengawasan eksternal terhadap pengelolaan dan tanggung jawab keuangan negara dari sisi pelaksanaan penggunaan Anggaran Pendapatan dan Belanja Negara atau Daerah serta terhadap kinerja pemerintahan. Dalam pelaksanaan tugas pemeriksaan pengelolaan dan tanggung jawab keuangan negara, BPK telah dijamin kebebasan dan kemandiriannya sebagaimana tercantum dalam Pasal 23E ayat (1) UUD 1945 yang berbunyi "Untuk memeriksa pengelolaan dan tanggung jawab tentang keuangan negara diadakan satu BPK yang bebas dan mandiri”. Pengertian bebas dan mandiri tersebut adalah BPK bebas dari pengaruh kekuasaan pemerintah meskipun posisinya tidak berada di atas pemerintah (Ariyanto \& Jati, 2010). Sementara mandiri berarti BPK memiliki kemandirian dalam melaksanakan tugas pemeriksaannya, di antaranya mandiri dalam menetapkan prosedur dan standar dalam pelaksanaan pemeriksaan pengelolaan dan tanggung jawab keuangan negara (Aferio, 2015). Kewenangan yang diperoleh BPK dalam melaksanakan tugas pemeriksaan pengelolaan dan tanggung jawab keuangan negara tersebut diberikan secara langsung oleh UUD 1945 maupun Undang-Undang, khususnya UndangUndang Nomor 15 Tahun 2004 tentang Pemeriksaan Pengelolaan dan Tanggung Jawab Keuangan Negara (UU Pemeriksaan) dan Undang-Undang Nomor 15 Tahun 2006 tentang BPK (UU BPK).

Hal inilah yang menjadi suatu hal yang harus dianalisis secara mendalam dan komprehensif terkait bagaimana mekanisme pelimpahan kewenangan BPK kepada Pelaksana BPK dan pemeriksa dan/atau tenaga ahli dari luar BPK yang bekerja untuk dan atas nama BPK karena masih terdapat pihak-pihak yang mempermasalahkan pelimpahan kewenangan BPK dalam melakukan tugas pemeriksaan pengelolaan dan tanggung jawab keuangan negara, bahkan melakukan gugatan ke Pengadilan Tata Usaha Negara (TUN) atas pelimpahan kewenangan tersebut (Astuti \& Sa'adah, 2019). Gugatan TUN tersebut di atas sebagai bentuk risiko hukum BPK dalam pelaksanaan kewenangan pemeriksaan pengelolaan dan tanggung 
jawab keuangan negara dapat mengakibatkan turunnya reputasi BPK sehingga tingkat kepercayaan masyarakat kepada BPK menjadi rendah dan tidak terwujudnya asas kepastian hukum atas pelaksanaan kewenangan BPK sebagaimana telah diatur dalam konstitusi.

Dalam menjalankan tugas dan wewenang BPK, pimpinan BPK dapat melimpahkan kewenangannya kepada pejabat di bawahnya. Pasal 34 ayat (1) UU BPK mengatur bahwa BPK dibantu oleh Pelaksana BPK yang terdiri atas Sekretariat Jenderal, unit pelaksana tugas pemeriksaan, unit pelaksana tugas penunjang, perwakilan, pemeriksa, dan pejabat lain yang ditetapkan oleh BPK sesuai dengan kebutuhan. Kata "dibantu" dalam Pasal 34 ayat (1) tersebut tidak menjelaskan bentuk pelimpahan kewenangan dari BPK kepada Pelaksana BPK dalam pelaksanaan tugas pemeriksaan pengelolaan dan tanggung jawab keuangan negara. Meski demikian, BPK belum mengatur secara jelas dan tegas bentuk dan prosedur pelimpahan kewenangan dari BPK dalam pelaksanaan tugas pemeriksaan pengelolaan dan tanggung jawab keuangan negara, sesuai pengaturan mengenai sumber kewenangan berdasarkan Undang-Undang Nomor 30 Tahun 2014 tentang Administrasi Pemerintahan (UU Administrasi Pemerintahan).

Penelitian ini berfokus pada pelimpahan kewenangan dan model pelimpahan kewenangan BPK dalam pelaksanaan tugas pemeriksaan pengelolaan dan tanggung jawab keuangan negara, khususnya pelimpahan kewenangan BPK kepada Pelaksana BPK, dan pemeriksa dan/atau tenaga ahli dari luar BPK yang bekerja untuk dan atas nama BPK, pasca berlakunya Undang-Undang Administrasi Pemerintahan. Identifikasi dan perumusan model pelimpahan kewenangan secara komprehensif, khususnya terkait bentuk dan prosedur pelimpahan kewenangan BPK kepada Pelaksana BPK, dan pemeriksa dan/atau tenaga ahli dari luar BPK yang bekerja untuk dan atas nama BPK, yang dapat dikembangkan bagi BPK menjadi tujuan dari penelitian ini.

\section{B. TINJAUAN PUSTAKA}

Beberapa penelitian terdahulu terkait dengan kewenangan BPK berfokus kepada kewenangan pemeriksaan BPK terhadap Badan Usaha Milik Negara (BUMN) (Anggoro, 2018), kepastian hukum kewenangan BPK memeriksa dokumen rahasia wajib pajak (Mening, 2016), peran BPK dalam melakukan pemeriksaan terhadap pengelolaan keuangan negara (Raba', 2017), dan pelimpahan kewenangan BPK kepada perwakilan BPK dalam pemeriksaan di daerah (Astuti \& Sa'adah, 2019).

Beberapa penelitian terdahulu ini menyimpulkan bahwa kewenangan pemeriksaan BPK memiliki asas hukum yang jelas, namun masih memiliki kendala yang kompleks di dalam implementasinya. Penelitian-penelitian tersebut belum memberikan sebuah model pelimpahan kewenangan BPK yang komprehensif karena masih terfragmentasi kepada beberapa aspek yang terpisah, seperti dasar hukum, dokumen rahasia, atau terhadap objek negara seperti BUMN. Research gap ini yang kemudian hendak difokuskan oleh penelitian ini dengan memformulasikan model pelimpahan kewenangan yang lebih komprehensif.

Penggunaan teori dalam penulisan penelitian ini dilakukan secara berjenjang mulai dari grand theory menggunakan teori dan konsep pemerintahan, middle range theory menggunakan teori dan konsep manajemen pemerintahan, dan teori dan konsep tata kelola pemerintahan yang baik (good governance). Sedangkan applied theory menggunakan teori 
dan konsep kewenangan dan pelimpahan kewenangan, teori dan konsep fungsi pengawasan dan auditing, dan teori dan konsep rekonstruksi model, untuk dapat merancang model pelimpahan kewenangan BPK secara komprehensif dalam pelaksanaan tugas pemeriksaan pengelolaan dan tanggung jawab keuangan negara yang tepat dan ideal. Fokus kepada ketiga applied theory dijabarkan di dalam bagian berikut:

1. Kewenangan dan Pelimpahan Kewenangan

Kewenangan tidak terlepas dari pembagian urusan kekuasaan (McMahon, 2017, hlm. 25). Pembagian urusan pemerintahan didasarkan pada teori pembagian kekuasaan yang dikenal sebagai doktrin "Trias Politica". Montesquieu menyatakan "When the legislative and executive power are united same person they can be no liberty, because apprehensions may arise, let the same monarch or senate should enact tyrannical laws to execute them a tyrannical manner again, there is no liberty if the judicial power be not separated from the legislative and executive. (Ketika kekuasaan legislatif dan eksekutif dipegang oleh satu orang yang sama tidak ada kebebasan, sebab hal tersebut dapat menimbulkan monarki atau bersifat tirani, demikian juga kekuasaan judikatif tidak dipisahkan dari kekuasaan legislatif dan eksekutif) (Juanda, 2008:29).

Teori kewenangan dari Max Webber menjelaskan bahwa kewenangan yang dijalankan oleh pemerintahan adalah sesuatu yang sah secara hukum (Beetham, 2018, hlm. 67). Kewenangan (authority) adalah kekuasaan yang sah (legitimate power) atau kekuasaan yang terlembagakan (institutionalized power). Menurut Max Webber, ada tiga jenis kewenangan yakni kewenangan tradisional, kewenangan kharismatik, dan kewenangan rasional (Beetham, 2018:67-69).

Teori kewenangan (authority), kekuasaan (power) dan pengaruh (influence) oleh Stoner, Freeman, dan Gilbert (1994) menjelaskan bahwa kewenangan (authority) sudah pasti sebuah kekuasaan (power), tetapi kekuasaan belum tentu kewenangan. Kewenangan formal berakar dari pemahaman umum bahwa orang-orang atau kelompok tertentu memiliki hak untuk menggunakan pengaruhnya dalam batas tertentu melalui kedudukannya di dalam organisasi. Dengan perkataan lain, kewenangan berkaitan erat dengan kedudukan seseorang atau kelompok dalam suatu organisasi. Formal authority disebut juga sebagai legitimate power, karena dalam menjalankan kekuasaannya, seseorang atau sebuah organisasi telah diberi legitimasi melalui peraturan perundang-undangan (Sebele, 2013).

Pada sisi lain, kekuasaan adalah kemampuan untuk menggunakan pengaruh, yakni kemampuan untuk mengubah sikap dan perilaku seseroang atau kelompok, agar mau mengikuti apa yang diinginkan oleh orang yang menggunakan kekuasaannya. Stoner, Freeman, dan Gilbert (1994) menegaskan ada dua sudut pandang melihat kewenangan, yakni sudut pandang klasik (the classic view) dan sudut pandang penerima kewenangan (the acceptance view). Menurut pandangan klasik, kewenangan aslinya datang dari tingkatan sangat tinggi (biasanya dari Tuhan atau negara yang berada di tangan raja, diktator, atau presiden terpilih) dan kemudian berdasarkan peraturan perundang-undangan turun ke bawah aras demi aras. Tetapi kewenangan juga dapat datang dari kehendak bersama dari masyarakat. Menurut sudut pandang penerima, lebih menekankan posisi penerima pengaruh daripada pemberi pengaruh, sebab tidak semua aturan hukum dan perintah dapat diterima oleh semua pihak (Keping, 2018). Ada pihak yang menerima, ada pula yang menolak. 
Kewenangan dalam organisasi pemerintah lebih banyak dilihat dari sudut pandang pertama, karena sifatnya yang hierarkis. Sumber kewenangan yang ada pada aras bawah berasal dari aras atas, atau dari eselon yang lebih tinggi ke eselon yang lebih rendah. Demikian pula, hubungan antara pemerintah dengan masyarakat juga bersifat atas bawah. Akan tetapi sering perubahan paradigma menuju tata pemerintahan yang baik (good governance), hubungan antara pemerintah dengan masyarakat berubah menjadi hierarkis. Tiga domain yang ada pada paradigma good governance yakni public sector, private sector, dan society berada dalam keadaan sejajar, yang berbeda hanya fungsinya (Safkaur dkk., 2019).

Berdasarkan pendekatan manajemen, agar pelimpahan kewenangan dapat berjalan secara efektif, maka dalam pelaksanaannya perlu memperhatikan prinsip-prinsip tertentu. Menurut teori yang disampaikan Koontz dan Weihrich (2008:184-186) terdapat tujuh prinsip untuk melakukan pelimpahan kewenangan, yaitu: Principle of delegation by expected results (Prinsip pelimpahan kewenangan berdasarkan hasil yang diharapkan). Maksudnya adalah bahwa pelimpahan kewenangan diberikan berdasarkan tujuan dan rencana yang telah disiapkan sebelumnya. Perlu tidaknya sebuah kewenangan dilimpahkan, akan tergantung kepada hasil yang diharapkan, apakah akan menguntungkan bagi pencapaian tujuan organisasi atau bahkan cenderung merugikan organisasi.

Principle of functional definition (Pelimpahan kewenangan berdasarkan prinsip definisi fungsional). Prinsip ini dimaksudkan bahwa pelimpahan kewenangan hendaknya didasarkan pada pertimbangan-pertimbangan fungsional agar pekerjaan atau tugas tertentu dapat dilaksanakan secara lebih efektif dan efisien. Prinsip ini lebih menekankan pada ketepatan arah pelimpahan kewenangan sesuai dengan fungsi dari pihak penerima pelimpahan kewenangan. Tidak diharapkan adanya pelimpahan kewenangan kepada unit atau orang yang secara fungsional tidak atau kurang terkait.

Scalar principle (Prinsip berurutan berdasarkan hierarki jabatan). Kewenangan yang diberikan hendaknya dilimpahkan secara berurutan dari jabatan tertinggi hingga jabatan di bawahnya. Hal ini dimaksudkan agar kewenangan-kewenangan pada setiap level jabatan lebih jelas tingkat proporsi ataupun substansinya.

Authority level principle (Prinsip jenjang kewenangan). Prinsip ini mengharapkan adanya kewenangan yang dilimpahkan secara bertahap berdasarkan tingkat kewenangan yang dimiliki pejabat atau satu unit organisasi tertentu. Prinsip ini erat kaitannya dengan prinsip ketiga dimana jenjang hierarki akan berimplikasi kepada tahapan-tahapan pelimpahan kewenangan, baik tahapan dalam arti proses maupun tahapan dalam arti struktur atau tingkatan organisasi.

Principle of unity of command (Prinsip yang lebih menekankan akan pentingnya satu kesatuan komando dalam pelimpahan kewenangan). Dengan adanya kesatuan komando, dapat dihindari kesimpangsiuran ataupun tumpang tindih kegiatan dan tanggung jawab. Apa yang harus dilakukan dan kepada siapa harus bertanggung jawab akan menjadi lebih jelas arahnya.

Principle of absoluteness of responsibility (Prinsip pelimpahan kewenangan yang diimbangi dengan pemberian tanggung jawab yang penuh). Pihak yang melimpahkan kewenangan tidak seharusnya terlalu campur tangan terhadap urusan yang sudah dilimpahkan. 
Oleh karena itu, nilai-nilai kepercayaan menjadi faktor utama sehingga pihak penerima pelimpahan kewenangan dapat mengambil keputusan dengan berbagai risikonya yang harus dipertanggungjawabkan kepada pihak yang memberikan kewenangan.

Principle of parity of authority and responsibility (Prinsip keseimbangan antara kewenangan dan tanggung jawab). Artinya bahwa kewenangan yang dilimpahkan secara bersamaan diberikan dengan tanggung jawab yang seimbang. Dalam hal ini, proporsi pertanggungjawaban sesuai dengan proporsi kewenangan yang diberikan.

Prinsip-prinsip ini akan digunakan sebagai dasar formulasi model pelimpahan kewenangan BPK.

2. Fungsi Pengawasan dan Auditing

Dalam menilai bekerjanya manajemen kebijakan dalam masyarakat, ada suatu model evaluasi dan penilaian yang dinamakan efisiensi pareto (Suzumura, 1981). Model ini menilai bekerjanya manajemen kebijakan publik sebagai suatu perubahan dalam organisasi ekonomi yang memberikan kemajuan positif setiap orang atau lebih tepatnya, membuat suatu atau lebih anggota masyarakat menjadi lebih baik tanpa merugikan semua anggota masyarakat lainnya. Dalam kaitannya dengan bekerjanya suatu kebijakan, akan dapat berhasil jika memberikan kemajuan positif masyarakat atau memberikan suatu perubahan yang lebih baik kepada anggota masyarakat, tanpa dampak negatif. Konsep ini dipandang sebagai paradigma baru dalam manajemen pemerintahan, yang meletakkan konsep pengawasan sebagai alat untuk menilai berjalannya manajemen pemerintahan negara secara terukur dalam tataran struktur dan fungsinya (Grandy, 2009).

Konsep manajemen kebijakan yang berpijak pada kemajuan positif tanpa melakukan penyimpangan terhadap ketentuan peraturan perundang-undangan merupakan konsep pengawasan. Untuk mengukur hal tersebut diperlukan lembaga yang berfungsi melakukan pengawasan terhadap struktur maupun fungsi pemerintahan. Adanya efisiensi pareto hanya dapat terjadi dalam kondisi adanya daya tanggap alat pengawasan yang efektif dan pertanggungjawaban aparatur administrasi negara administrasi negara untuk menjalankan efektivitas program (Bromley, 1990).

Pengawasan (controling) dan pemeriksaan (auditing) merupakan bagian yang selalu melekat (inheren) dalam sebuah sistem manajemen. Sebagaimana diketahui, dalam sebuah sistem manajemen terdapat fungsi perencanaan (planning), pelaksanaan (actuating), pengawasan (controlling) atau pemeriksaan (auditing) serta evaluasi (monitoring). Unsurunsur tersebut bekerja saling melengkapi dalam satu kesatuan dan saling terkait (Akbar, 2012:43). Stephen P. Robbins menjelaskan arti pengawasan sebagai berikut: “... the process of monitoring activities to ensure they are being accomplished as planned and correcting any significant divisions. Hal ini menyatakan bahwa pengawasan adalah suatu proses pengamatan (monitoring) terhadap suatu pekerjaan, untuk menjamin pekerjaan tersebut selesai sesuai dengan yang direncanakan, dengan pengoreksian beberapa pemikiran yang saling berhubungan (Akbar, 2012:46).

Pada dasarnya, pengawasan terhadap keuangan negara dapat diklasifikasikan menjadi pengawasan internal dan pengawasan eksternal. Pengawasan internal adalah pengawasan yang dilakukan oleh lembaga pengawas internal, yaitu lembaga yang berada dalam struktur 
pemerintah atau eksekutif. Pengawasan ini terdiri dari pengawasan atasan langsung atau pengawasan melekat dan pengawasan fungsional (Fahrojih, 2016:46).

Pengawasan eksternal adalah suatu bentuk pengawasan yang dilakukan oleh suatu unit pengawasan yang sama sekali berasal dari luar lingkungan eksekutif. Dengan demikian, antara pengawas dan pihak yang diawasi tidak lagi ada hubungan kedinasan. Lembaga yang melakukan pengawasan eksternal adalah DPR atau DPRD dan BPK (Fahrojih, 2016:47).

3. Rekonstruksi Model

Analisis yang berbasis model penting dilakukan tahapan untuk menentukan atau menyusun model yang dapat memahami keterkaitan permasalahan sehingga diharapkan memberikan efek perubahan perilaku pada sistem nyata yang diteliti. Kaplan di dalam Shoemaker (2003) selanjutnya menyatakan "sometimes the word is used to represent a model of a theory which presents the letter purely as a structure of uninterpreted symbol". Berdasarkan pendapat di atas maka pengertian yang disampaikan dalam membentuk sebuah model diharapkan berfungsi untuk memberikan gambaran atau deskripsi, memberikan penjelasan dan pola alur pemikiran berupa gambar.

Secara konseptual paradigma pemodelan juga dapat dinyatakan dalam dua pandangan umum yakni: 1) pemodelan mengandung suatu ide atau gagasan dan dihubungkan melalui bahasa yang lebih sederhana; dan 2) pemodelan mengatur pembuat model dalam bentuk rangkaian yang menggambarkan suatu fenomena dalam sebuah sistem (Jackson, 2007, hlm. 105). Hal ini juga memberikan pemahaman baru bahwa model akan menunjukkan kerangka nyata dalam suatu proses kegiatan. Untuk melakukan pemodelan maka diperlukan sebuah pendekatan struktur yang merupakan bagian dari sistem berpikir (system thinking) baru. Penggunaan system thinking perlu memahami bahwa suatu struktur fisik dan struktur pengambilan keputusan merupakan yang saling tergantung satu dengan yang lain yang dikenal dengan hubungan kausal atau sebab akibat.

\section{METODE}

Penelitian ini menggunakan desain penelitian kualitatif. Metode kualitatif biasa digunakan untuk meneliti permasalahan yang mempunyai ruang lingkup terperinci yang dikaji secara mendalam, utuh dan menyeluruh (holistik) serta bukan merupakan kajian parsial. Fokus penelitian pada jenis penelitian kualitatif berkaitan erat dengan perumusan masalah karena masalah penelitian menjadi acuan dalam menentukan fokus penelitian. Akan tetapi, mengingat metode penelitian kualitatif bersifat fleksibel, maka fokus penelitian dapat saja berkembang sesuai dengan situasi penelitian di lapangan dan sesuai dengan hasil akhir pengumpulan data yang sebenarnya di lapangan. Berdasarkan masalah dan tujuan penelitian yang telah dirumuskan, maka ditentukan dua fokus penelitian: 1) pelimpahan kewenangan BPK dalam melaksanakan tugas pemeriksaan pengelolaan dan tanggung jawab keuangan negara; dan 2) model pelimpahan kewenangan yang dapat dikembangkan bagi BPK dalam melaksanakan tugas pemeriksaan pengelolaan dan tanggung jawab keuangan negara.

Data yang dimanfaatkan dalam penelitian bersumber dari data primer dan data sekunder. Data primer diperoleh langsung oleh peneliti melalui in-depth interview dengan unsur pimpinan BPK dan pejabat struktural BPK terkait penyusunan desain pelimpahan kewenangan BPK, serta Pelaksana BPK dan pemeriksa dan/atau tenaga ahli dari luar BPK 
yang bekerja untuk dan atas nama BPK terkait penerima pelimpahan kewenangan BPK. Sedangkan pemenuhan kebutuhan data sekunder dilakukan dengan memanfaatkan dokumendokumen resmi yang berhubungan dengan proses penyusunan desain dan implementasi kebijakan terkait pelimpahan kewenangan BPK dalam pelaksanaan tugas atas pemeriksaan pengelolaan dan tanggung jawab keuangan negara.

\section{HASIL DAN PEMBAHASAN}

\section{Pelimpahan Kewenangan BPK kepada Pelaksana BPK}

Pelimpahan kewenangan BPK dalam pemeriksaan pengelolaan dan tanggung jawab keuangan negara kepada Pelaksana BPK dhi. Kepala BPK Perwakilan, diatur berdasarkan kewenangan BPK dalam melaksanakan pemeriksaan pengelolaan keuangan negara merupakan kewenangan yang diperoleh secara atribusi berdasarkan Pasal 23E ayat (1) UUD 1945 yang berbunyi "untuk memeriksa pengelolaan dan tanggung jawab tentang keuangan negara diadakan satu BPK yang bebas dan mandiri." Dari ketentuan tersebut dapat disimpulkan bahwa negara menghendaki dalam rangka memeriksa pengelolaan dan tanggung jawab tentang keuangan negara, diadakan satu BPK yang bebas dan mandiri. Selanjutnya perihal BPK diatur dalam UU BPK termasuk dalam hal ini terkait kedudukan dan kewenangannya (Paputungan, 2017).

Dalam pelaksanaan kewenangannya memeriksa pengelolaan dan tanggung jawab tentang keuangan negara, BPK yang terdiri dari 9 (sembilan) orang anggota secara atributif berdasarkan UU BPK berwenang salah satunya untuk menentukan objek pemeriksaan, merencanakan dan melaksanakan pemeriksaan, menentukan waktu dan metode pemeriksaan serta menyusun dan menyajikan laporan pemeriksaan.

Dalam pelaksanaan kewenangan dimaksud, BPK dibantu oleh Pelaksana BPK yang terdiri atas Sekretariat Jenderal, unit pelaksana tugas pemeriksaan, unit pelaksana tugas penunjang, perwakilan, pemeriksa, dan pejabat lain yang ditetapkan oleh BPK sesuai dengan kebutuhan. Frasa "dibantu oleh Pelaksana BPK" mengacu pada pemberian dukungan atas kewenangan atribusi yang dimiliki oleh BPK. Ketentuan tersebut secara tidak langsung memberikan pengertian bahwa BPK diperbolehkan untuk melimpahkan sebagian wewenang atau urusannya melalui pembagian tugas kepada Pelaksana BPK (Adrian, 2013).

Dengan demikian secara administrasi pemerintahan peran yang dimiliki oleh Pelaksana BPK sebagaimana dimaksud, merupakan bentuk pelimpahan wewenang berdasarkan UU BPK. Perihal tersebut merupakan pemahaman dasar atas lahirnya proses pelimpahan wewenang dari BPK kepada Pelaksana BPK.

Namun apabila melihat praktik dalam proses pelimpahan kewenangan yang berlaku pada badan dan/atau pejabat pemerintahan yang menyelenggarakan fungsi pemerintahan, penggunaan frasa "dibantu" sebenarnya tidak dikenal sebagai bentuk pelimpahan kewenangan. Sebagaimana diatur dalam UU Administrasi Pemerintahan, pelimpahan kewenangan yang berlaku pada badan dan/atau pejabat pemerintahan yang menyelenggarakan Fungsi Pemerintahan hanya terdiri atas Atribusi, Delegasi, dan/atau Mandat.

Dengan demikian, penggunaan frasa "dibantu" dalam Pasal 34 ayat (1) UU BPK menimbulkan ketidakselarasan dengan praktik pelimpahan wewenang yang ada dalam ranah 
administrasi pemerintahan. Lebih lanjut tidak ada ketentuan undang-undang lain yang mempertegas perihal bentuk pelimpahan kewenangan dari BPK kepada Pelaksana BPK. Hal tersebut mengakibatkan kebebasan dalam mendefinisikan bentuk pelimpahan kewenangan BPK kepada Pelaksana BPK. Namun demikian, berdasarkan UU BPK diatur bahwa ketentuan lebih lanjut mengenai tata cara pelaksanaan wewenang BPK, diatur dengan Peraturan BPK. Sebagai ketentuan lebih lanjut pelaksanaan wewenang BPK, Peraturan BPK Nomor 1 Tahun 2019 tentang Organisasi dan Tata Kerja Pelaksana BPK mengatur bahwa kewenangan dalam pelaksanaan tugas pemeriksaan diserahkan kepada Auditorat Utama Keuangan Negara (AKN) yang berada di bawah dan bertanggung jawab kepada BPK melalui Anggota BPK yang ditetapkan BPK.

Kepala BPK Perwakilan memperoleh pelimpahan wewenang dari BPK dan bertanggung jawab kepada BPK melalui Auditor Utama Keuangan Negara. Apabila dilihat dari sudut pandang pertanggungjawaban dalam pelaksanaan pemeriksaan, baik pada unit Auditorat atau BPK Perwakilan, maka bentuk pelimpahan wewenang yang sesuai untuk mendefinisikan frasa "dibantu oleh Pelaksana BPK" adalah mandat. Sehingga dalam perkembangannya, BPK telah mengatur secara jelas dan tegas pelimpahan kewenangan BPK kepada Pelaksana BPK dhi. Auditor Utama Investigasi dalam bentuk Keputusan BPK.

Hasil penelitian menunjukkan bahwa manajemen dan keahlian Tim Pemeriksa telah diatur oleh BPK dalam Standar Pemeriksaan Keuangan Negara (SPKN). SPKN mengatur bahwa BPK menjamin Pemeriksa memiliki keahlian yang diperlukan. Tim Pemeriksa harus secara kolektif memiliki pengetahuan, pengalaman, dan kompetensi yang diperlukan dalam Pemeriksaan. Hal ini termasuk pengetahuan dan pengalaman praktis dari Pemeriksaan yang dilakukan, pemahaman atas standar dan ketentuan peraturan perundang-undangan, pemahaman tentang operasional entitas, serta kemampuan dan pengalaman untuk mempraktikkan pertimbangan profesional. BPK merekrut sumber daya manusia dengan kualifikasi yang sesuai, memberikan pelatihan dan pengembangan kapasitas, menyiapkan standar dan pedoman pemeriksaan, serta menyediakan sumber daya pemeriksaan yang cukup.

Pemeriksa menjaga kompetensi profesional mereka melalui pengembangan profesional berkelanjutan. Pengembangan kapasitas pemeriksa mencakup pertukaran ide dan pengalaman pemeriksaan dengan komunitas pemeriksa internasional. Hal tersebut diwujudkan dalam kongres, pelatihan, seminar, dan kelompok kerja di tingkat internasional. Pemeriksa dapat menggunakan hasil pekerjaan Aparat Pengawasan Intern Pemerintah (APIP), tenaga ahli dan/atau tenaga pemeriksa di luar BPK. Prosedur pemeriksaan harus memberikan dasar yang cukup saat menggunakan hasil kerja pihak lain. Pemeriksa harus memperoleh bukti yang menjamin kompetensi dan independensi tenaga ahli dan/atau tenaga pemeriksa di luar BPK, serta kualitas hasil pekerjaannya.

\section{Pelimpahan Kewenangan BPK kepada Tenaga Ahli dan/atau Tenaga Pemeriksa di Luar BPK}

Hasil penelitian terhadap peraturan perundangan-undangan terkait pelimpahan kewenangan dari BPK kepada tenaga ahli dan/atau tenaga pemeriksa di luar BPK, berdasarkan Pasal 9 ayat (1) huruf g UU BPK mengatur bahwa dalam melaksanakan tugasnya, BPK berwenang menggunakan tenaga ahli dan/atau tenaga pemeriksa di luar BPK 
yang bekerja untuk dan atas nama BPK. Selanjutnya telah ditetapkan Peraturan BPK Nomor 1 Tahun 2008 tentang Penggunaan Pemeriksa dan/atau Tenaga Ahli dari Luar BPK, untuk melaksanakan ketentuan Pasal 3 ayat (2) dan Pasal 9 ayat (3) UU Pemeriksaan serta Pasal 6 ayat (4) dan Pasal 9 ayat (1) huruf g UU BPK.

BPK dapat menggunakan tenaga pemeriksa di luar BPK dan harus independen serta memiliki kompetensi yang diperlukan. Kompetensi tenaga pemeriksa di luar BPK dibuktikan dengan sertifikat profesional yang diterbitkan oleh lembaga yang berwenang atau dokumen lainnya yang menyatakan keahlian.

Hasil analisis terhadap penggunaan tenaga pemeriksa di luar BPK yang bekerja untuk dan atas nama BPK dari lingkungan APIP diketahui berdasarkan Peraturan Pemerintah Nomor 60 Tahun 2008 tentang Sistem Pengendalian Intern Pemerintah, Badan Pengawasan Keuangan dan Pembangunan (BPKP) telah melakukan sinergi dengan seluruh inspektorat pemerintah, mulai dari Inspektorat Jenderal Kementerian/Lembaga, Inspektorat Provinsi hingga Inspektorat Kabupaten/Kota. Sejak disahkannya Peraturan Presiden Nomor 194 Tahun 2014, kewajiban sinergi menjadi lebih kuat. Sinergi BPKP dengan inspektorat, dilakukan dalam hal reviu atas penyerapan anggaran dan dukungan terhadap agenda penegakan hukum. Fungsi pengawasan yang dilakukan BPKP terbatas pada lembaga pemerintah dan bukan lembaga negara.

Hal ini berarti bahwa hubungan dengan lembaga negara dalam hal ini BPK sebenarnya tidak sejajar. BPKP sebagai Lembaga Pemerintah Non Departemen (LPND) mengawasi keuangan internal pemerintah atau berperan sebagai auditor internal, sementara BPK sebagai lembaga tinggi negara memeriksa dan mengawasi keuangan pemerintah, atau bertindak sebagai pemeriksa eksternal.

Namun demikian, walaupun memiliki tugas dan wewenang yang berbeda, BPK dan BPKP telah melakukan sinergi dan koordinasi dengan sangat baik, utamanya dalam rangka peningkatan kualitas dan akuntabilitas pengelolaan dan tanggung jawab keuangan negara. Sinergi dan koordinasi yang dilakukan oleh BPK dan BPKP tersebut telah memberikan kontribusi yang sangat besar dalam peningkatan kualitas dan akuntabilitas pengelolaan dan tanggung jawab keuangan negara, melalui rekomendasi-rekomendasi hasil pemeriksaan yang didasarkan pada proses pemeriksaan keuangan negara serta pengawasan intern pemerintah yang sesuai dengan standar-standar yang berlaku umum.

Selanjutnya berdasarkan Pasal 9 UU Pemeriksaan menyatakan bahwa dalam menyelenggarakan pemeriksaan pengelolaan dan tanggung jawab keuangan negara, BPK dapat memanfaatkan hasil pemeriksaan APIP. Berdasarkan ketentuan tersebut, dalam hal terdapat perbedaan atas rekomendasi hasil pemeriksaan antara BPK dan BPKP (termasuk hasil penghitungan kerugian), maka implementasi rekomendasi tersebut dikembalikan kepada kewenangan BPK dan BPKP yang telah diatur secara jelas dalam peraturan perundangundangan, sehingga tumpang tindih pemeriksaan tentunya dapat dihindari dengan adanya sinergi dan koordinasi yang sangat baik yang telah dilakukan oleh dua lembaga tersebut.

Hasil analisis terhadap jenis pemeriksaan yang dilakukan oleh pemeriksa dan/atau tenaga ahli dari luar BPK menunjukkan bahwa jenis pemeriksaan tersebut ditetapkan oleh BPK. Jenis pemeriksaan sebagaimana dimaksud pada ayat (1) terdiri atas pemeriksaan keuangan, pemeriksaan kinerja, atau pemeriksaan dengan tujuan tertentu sebagaimana 
dimaksud dalam Pasal 4 ayat (2), ayat (3), dan ayat (4) UU Pemeriksaan. Jenis pemeriksaan yang dilakukan oleh akuntan publik yang ditunjuk oleh pihak selain BPK adalah pemeriksaan keuangan.

\section{Prinsip-Prinsip Pelimpahan Kewenangan terhadap Pelimpahan Kewenangan BPK}

Berdasarkan hasil penelitian diketahui bahwa pelimpahan kewenangan BPK pada dasarnya sudah dilaksanakan cukup baik sesuai dengan 7 (tujuh) prinsip untuk melakukan pelimpahan wewenang menurut Koontz and Weihrich, walaupun terdapat beberapa prinsip yang masih harus ditingkatkan karena masih adanya beberapa indikator yang belum optimal.

Principle of Delegation by Expected Results. Berdasarkan hasil penelitian diketahui bahwa dalam pelimpahan kewenangan pelaksanaan tugas pemeriksaan yang dilakukan oleh BPK sudah sesuai dengan prinsip pelimpahan kewenangan berdasarkan hasil yang diperkirakan, hal ini dikarenakan dalam pelimpahan kewenangan telah memperhatikan perencanaan strategis BPK dan perencanaan untuk setiap penugasan pemeriksaan sehingga terdapat kesesuaian dalam pelaksanaan pelimpahan kewenangan dengan pelaksanaan tugas pemeriksaan.

Perencanaan strategis BPK adalah proses penyusunan visi dan misi yang disusun BPK setiap periode 5 (lima) tahunan dan tertuang dalam dokumen Rencana Strategis (Renstra). Renstra memuat visi dan misi BPK yang akan dicapai dalam periode 5 (lima) tahun, dan antara lain memuat kebijakan dan strategi pemeriksaan yang menjadi prioritas.

BPK telah menyusun Renstra BPK 2016-2020. Renstra BPK 2016-2020 merupakan Renstra ketiga BPK. Renstra BPK sepuluh (10) tahun sebelumnya menekankan pada pengembangan kelembagaan untuk mewujudkan BPK sebagai lembaga pemeriksa keuangan negara yang bebas dan mandiri, profesional, serta kredibel untuk berperan aktif atau mendorong pengelolaan keuangan negara yang akuntabel dan transparan.

Principle of Functional Definition. Berdasarkan hasil penelitian diketahui bahwa dalam pelimpahan kewenangan yang dilakukan oleh BPK belum sepenuhnya sesuai dengan prinsip definisi fungsional, hal ini dikarenakan dalam bentuk pelimpahan kewenangan BPK belum secara tegas dan jelas dicantumkan dalam uraian pekerjaan atau job description masing-masing Pelaksana BPK berdasarkan Peraturan BPK Nomor 1 Tahun 2019 tentang Organisasi dan Tata Kerja Pelaksana BPK.

Hasil analisis menunjukkan bahwa UU Administrasi Pemerintahan telah mengatur bahwa mandat adalah Pelimpahan Kewenangan dari Badan dan/atau Pejabat Pemerintahan yang lebih tinggi kepada Badan dan/atau Pejabat Pemerintahan yang lebih rendah dengan tanggung jawab dan tanggung gugat tetap berada pada pemberi mandat. Hasil analisis menunjukkan bahwa UU Administrasi Pemerintahan pada Pasal 12 ayat (3) telah mengatur bahwa kewenangan atribusi tidak dapat didelegasikan, kecuali diatur di dalam UUD 1945 dan/atau undang-undang.

Berdasarkan penjelasan tersebut di atas, diketahui bahwa terdapat ketidakselarasan antara pengaturan terkait pelimpahan kewenangan di BPK khususnya di SPKN dan Pedoman Manajemen Pemeriksaan (PMP) dengan UU Administrasi Pemerintahan. Sebagai bentuk kepatuhan BPK terhadap ketentuan yang diatur dalam UU Administrasi Pemerintahan, maka 
bentuk pelimpahan wewenang secara fungsional yang tepat dan ideal bagi BPK adalah tunduk pada pengaturan sesuai UU Administrasi Pemerintahan.

Scalar Principle. Berdasarkan hasil penelitian diketahui bahwa dalam pendelegasian wewenang yang dilakukan oleh BPK sudah sesuai dengan prinsip hierarki jabatan, hal ini dikarenakan dalam pelimpahan kewenangan BPK telah memperhatikan urutan kedudukan dari masing-masing Pelaksana BPK. Prinsip ini menghendaki adanya urutan-urutan wewenang dari pimpinan puncak ke bawahan. Menurut prinsip ini setiap bawahan harus diusahakan agar hanya menerima perintah dari seseorang atasan saja. Tapi seorang atasan dapat memerintah lebih dari seorang bawahan. Prinsip bahwa setiap bawahan harus diusahakan agar hanya menerima perintah dari seorang atasan relatif sulit diimplementasikan di BPK karena BPK dipimpin sembilan anggota dengan kepemimpinan yang bersifat kolektif kolegial. Pimpinan BPK terdiri atas seorang ketua merangkap anggota, seorang wakil ketua merangkap anggota, dan tujuh anggota.

Authority Level Principle. Berdasarkan hasil penelitian diketahui bahwa dalam pelimpahan kewenangan yang dilakukan oleh BPK belum sepenuhnya sesuai dengan prinsip jenjang kewenangan hal ini dikarenakan dalam pelimpahan kewenangan kurang memperhatikan urutan kedudukan masing-masing Pelaksana BPK. Hal ini menimbulkan ketidaksesuaian antara pelimpahan kewenangan yang dilakukan oleh BPK kepada Pelaksana BPK, dikarenakan dalam pelimpahan kewenangan kurang memperhatikan kewenangan Pelaksana BPK dalam melaksanakan kebijakan dalam organisasi sehingga menyebabkan Pelaksana BPK yang menerima wewenang dari BPK tidak dapat mengambil keputusan karena bukan merupakan kewenangannya.

Dalam implementasinya, produk yang dikeluarkan BPK dhi. Laporan Hasil Pemeriksaan (LHP) dari BPK Perwakilan maka pihak yang menandatangani adalah Pelaksana BPK dhi. Kepala BPK Perwakilan sebagai penanggung jawab pemeriksaan tanpa mencantumkan atas nama (a.n.) BPK, sehingga implementasi tersebut bukan merupakan karakteristik kewenangan mandat. Dengan demikian terdapat ketidakselarasan antara ketentuan peraturan perundang-undangan dengan implementasi.

Principle of Unity of Command. Berdasarkan hasil penelitian diketahui bahwa dalam pelimpahan kewenangan yang dilakukan oleh BPK sudah sesuai dengan prinsip yang lebih menekankan akan pentingnya satu kesatuan komando dalam pendelegasian kewenangan, hal ini dikarenakan BPK telah ditetapkan Renstra yang memuat visi dan misi BPK yang akan dicapai dalam periode 5 (lima) tahun, dan antara lain memuat kebijakan dan strategi pemeriksaan yang menjadi prioritas. Selain Renstra, berdasarkan pengaturan pada Organisasi Tata Kerja Pelaksana BPK diketahui tidak terdapat tumpang tindih pekerjaan yang disebabkan pelimpahan kewenangan tidak didasarkan pada urutan atau kedudukan Pelaksana BPK di dalam organisasi.

Principle of Absoluteness of Responsibility. Berdasarkan hasil penelitian diketahui bahwa dalam pelimpahan kewenangan yang dilakukan oleh BPK sudah sepenuhnya sesuai dengan prinsip pelimpahan kewenangan yang diimbangi dengan pemberian tanggung jawab yang penuh, hal ini ditunjukkan bahwa dalam pelaksanaan pemeriksaan, pemeriksa memiliki nilai independensi dalam tanggung jawab profesionalnya. Berdasarkan pengaturan terkait pelimpahan kewenangan dan analisis terhadap pelimpahan kewenangan BPK diketahui 
bahwa bentuk kewenangan tidak dinyatakan secara tegas, walaupun secara karakteristik termasuk dalam bentuk mandat, sedangkan dalam mandat diketahui bahwa tanggung jawab dan tanggung gugat tetap berada pada pemberi mandat. Menurut prinsip ini besarnya wewenang yang dilimpahkan harus sama dan seimbang dengan besarannya tugas dan tanggung jawab yang diminta. Tanpa keseimbangan antara wewenang dan tanggung jawab akan berakibat terjadinya kebuntuan dalam pelaksanaan tugas-tugas dan tumpang tindih.

Principle of Parity of Authority and Responsibility. Prinsip ini menyatakan bahwa setiap penerima wewenang, mutlak harus bertanggung jawab kepada pemberi wewenang mengenai wewenang yang dilaksanakannya. Berdasarkan hasil penelitian dan definisi prinsip tersebut terdapat ketidaksesuaian antara pelimpahan kewenangan yang dilakukan oleh BPK kepada Pelaksana BPK, hal ini dikarenakan dalam bentuk pelimpahan kewenangan belum dinyatakan secara tegas sehingga kurang memperhatikan keseimbangan antara kewenangan dan tanggung jawab masing-masing Pelaksana BPK, contohnya adalah adanya gugatan TUN terkait LHP yang ditujukan kepada Kepala BPK Perwakilan. Berdasarkan pengaturan terkait pelimpahan kewenangan dan analisis terhadap pelimpahan kewenangan BPK diketahui bahwa bentuk kewenangan tidak dinyatakan secara tegas, walaupun secara karakteristik termasuk dalam bentuk mandat.

\section{Model Pelimpahan Kewenangan BPK secara Komprehensif}

BPK diberikan kewenangan atribusi untuk memeriksa pengelolaan dan tanggung jawab keuangan negara berdasarkan UUD 1945 pada: 1) Pasal 23E ayat (1) yang mengatur bahwa untuk memeriksa pengelolaan dan tanggung jawab tentang keuangan negara diadakan satu BPK yang bebas dan mandiri; dan 2) Pasal 23G ayat (2) yang mengatur bahwa ketentuan lebih lanjut mengenai BPK diatur dengan undang-undang.

Menindaklanjuti ketentuan UUD 1945 tersebut, diterbitkan UU Pemeriksaan dan UU BPK. BPK dalam melaksanakan kewenangannya melimpahkan kewenangan tersebut kepada Pelaksana BPK. Bentuk pelimpahan kewenangan dalam UU BPK tidak dinyatakan secara tegas apakah dilakukan melalui delegasi atau mandat. Bentuk pelimpahan kewenangan dalam UU BPK di antaranya sebagai berikut: 1) Pasal 1 angka 10 yang mengatur bahwa Pemeriksa adalah orang yang melaksanakan tugas pemeriksaan pengelolaan dan tanggung jawab keuangan negara untuk dan atas nama BPK; 2) Pasal 9 ayat (1) huruf g yang mengatur bahwa dalam melaksanakan tugasnya, BPK berwenang menggunakan tenaga ahli dan/atau tenaga pemeriksa di luar BPK yang bekerja untuk dan atas nama BPK; 3) Pasal 34 ayat (1) yang mengatur bahwa BPK dalam menjalankan tugas dan wewenangnya dibantu oleh Pelaksana BPK, yang terdiri atas Sekretariat Jenderal, unit pelaksana tugas pemeriksaan, unit pelaksana tugas penunjang, perwakilan, Pemeriksa, dan pejabat lain yang ditetapkan oleh BPK sesuai dengan kebutuhan; dan 4) Pasal 34 ayat (3) yang mengatur bahwa dalam melaksanakan tugas pemeriksaan, BPK menggunakan Pemeriksa yang berstatus sebagai Pegawai Negeri Sipil atau yang bukan Pegawai Negeri Sipil.

Berdasarkan hasil penelitian maka model pelimpahan kewenangan yang dapat dikembangkan bagi BPK adalah model mandat tugas pemeriksaan secara komprehensif sebagai berikut: 


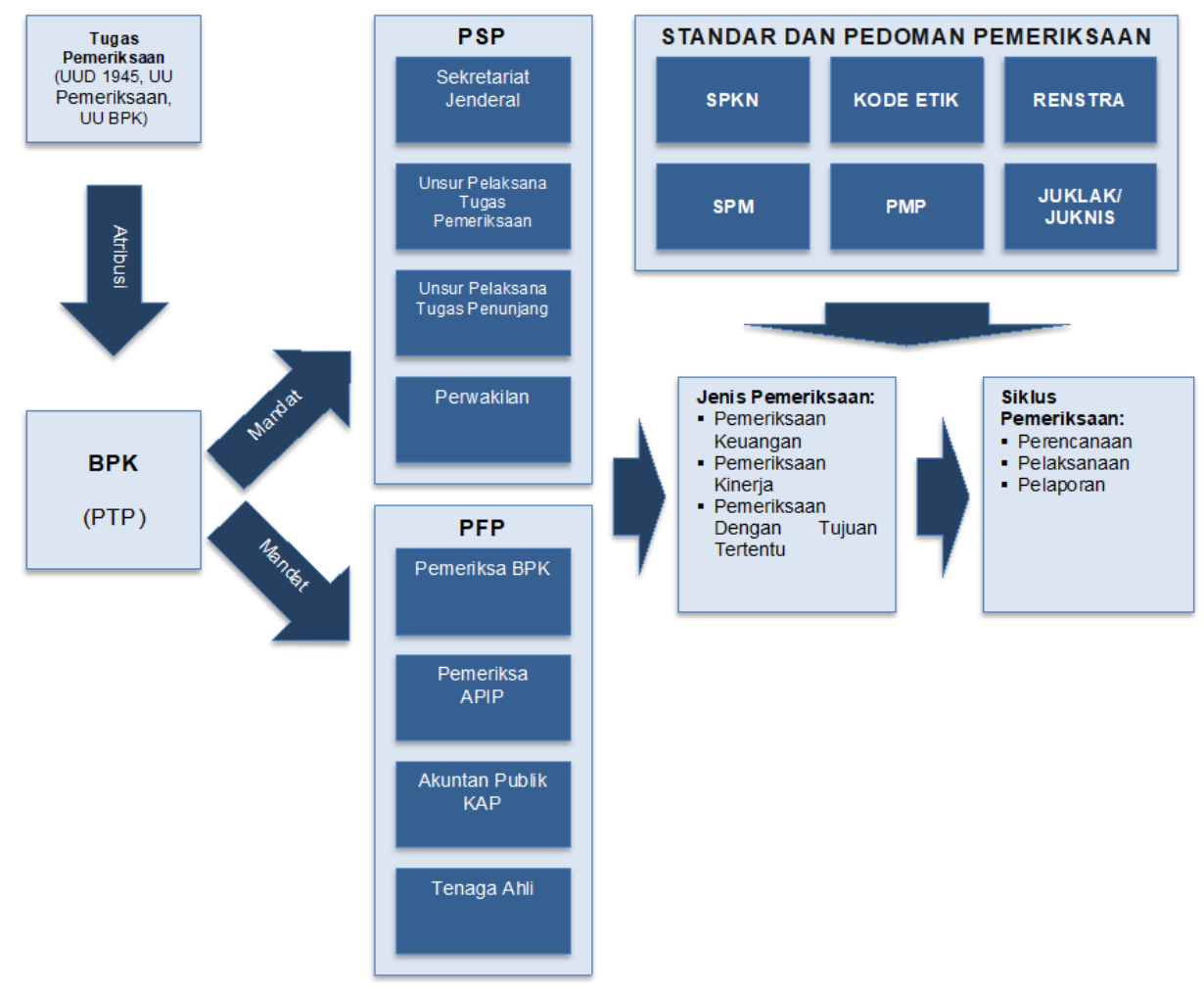

Gambar 1 Model Mandat Tugas Pemeriksaan Secara Komprehesif

Model mandat tugas pemeriksaan secara komprehensif merupakan gambaran terhadap pola pikir sebagai berikut:

BPK diberikan kewenangan atribusi sesuai UUD 1945, UU Pemeriksaan, dan UU BPK untuk melaksanakan tugas pemeriksaan pengelolaan dan tanggung jawab keuangan negara. Selanjutnya BPK sebagai Pemberi Tugas Pemeriksaan (PTP) melimpahkan kewenangan tugas pemeriksaan secara Mandat kepada Pejabat Struktural Pemeriksa (PSP) dan Pejabat Fungsional Pemeriksa (PFP). Pelimpahan kewenangan secara Mandat kepada PSP dilaksanakan karena adanya hubungan atasan dan bawahan, sedangkan pelimpahan kewenangan secara Mandat kepada PFP karena adanya penugasan pemeriksaan. PSP melaksanakan tugas sebagai unsur pelaksana, pendukung, dan menunjang tugas pemeriksaan, sedangkan PFP melaksanakan tugas pemeriksaan pengelolaan dan tanggung jawab keuangan negara untuk dan atas nama BPK.

Pelaksanaan tugas pemeriksaan dibagi menjadi 3 (tiga) jenis pemeriksaan, yaitu pemeriksaan keuangan, pemeriksaan kinerja, dan pemeriksaan dengan tujuan tertentu. Setelah penentuan jenis pemeriksaan, maka dilanjutkan dengan siklus pemeriksaan yang dibagi menjadi 3 (tiga), yaitu perencanaan, pelaksanaan, dan pelaporan pemeriksaan. Pelaksanaan tugas pemeriksaan secara komprehensif sesuai dengan jenis pemeriksaan yang ditentukan dan siklus pemeriksaan berdasarkan standar dan pedoman pemeriksaan yang berlaku di BPK, yaitu SPKN, Kode Etik, Renstra, Sistem Pengendalian Mutu (SPM), PMP, dan Petunjuk Pelaksanaan (Juklak) atau Petunjuk Teknis (Juknis) Pemeriksaan. BPK perlu menyadari konsekuensi atas model pelimpahan kewenangan melalui mandat tugas pemeriksaan secara komprehensif, dan konsekuensi apabila keputusan atau penandatanganan naskah dinas BPK 
dilakukan tidak sesuai dengan UU Administrasi Pemerintahan dan teori pelimpahan kewenangan, yaitu:

Dalam hal mandat, prosedur pelimpahan dalam rangka hubungan atasan bawahan yang bersifat rutin. Adapun tanggung jawab dan tanggung gugat tetap pada pemberi mandat. Mengingat bentuk pelimpahan wewenang bersifat mandat, maka semua penandatanganan harus sesuai ketentuan Pasal 14 ayat (4) UU Administrasi Pemerintahan, yakni Badan dan/atau Pejabat Pemerintahan yang menerima mandat harus menyebutkan atas nama Badan dan/atau Pejabat Pemerintahan yang memberikan mandat.

Apabila terdapat kesalahan karena tidak menggunakan penyebutan atas nama dalam produk sebagai hasil dari kewenangan BPK, misalnya LHP, maka secara administrasi produk tersebut dapat dicabut dan diganti dengan yang baru. Hal ini sifatnya kesalahan redaksional. BPK tidak harus melakukan pemeriksaan yang baru. Isi atau substansi LHP tersebut tidak menjadi batal atau tidak berlaku.

Model pelimpahan kewenangan melalui mandat tugas pemeriksaan secara komprehensif diharapkan dapat mewujudkan manfaat pemeriksaan keuangan negara yang dilaksanakan oleh BPK. Manfaat tersebut dapat ditunjukkan melalui pemeriksaan BPK yang mampu mendorong pengelolaan keuangan negara untuk mencapai tujuan negara, antara lain melalui: 1) penyediaan hasil pemeriksaan termasuk di dalamnya kesimpulan yang independen, objektif dan dapat diandalkan, berdasarkan bukti yang cukup dan tepat; 2) penguatan upaya pemberantasan korupsi berupa penyampaian temuan yang berindikasi tindak pidana dan/atau kerugian dalam pengelolaan keuangan negara kepada instansi yang berwenang untuk ditindaklanjuti, serta berupa pencegahan dengan penguatan sistem pengelolaan keuangan negara; 3) peningkatan akuntabilitas, transparansi, keekonomian, efisiensi, dan efektivitas dalam pengelolaan dan tanggung jawab keuangan negara, dalam bentuk rekomendasi yang konstruktif dan tindak lanjut yang efektif; 4) peningkatan kepatuhan pengelolaan dan pertanggungjawaban keuangan negara terhadap ketentuan peraturan perundang-undangan; 5) peningkatan efektivitas peran APIP; dan 6) peningkatan kepercayaan publik atas hasil pemeriksaan BPK dan pengelolaan keuangan negara.

\section{E. KESIMPULAN}

Sumber kewenangan kepada Badan dan/atau Pejabat Pemerintahan diatur dalam UU Administrasi Pemerintahan. BPK sebagai lembaga negara yang bebas dan mandiri diberikan kewenangan dalam pelaksanaan tugas pemeriksaan pengelolaan dan tanggung jawab keuangan negara berdasarkan UUD 1945, sehingga bentuk kewenangan BPK adalah atribusi. BPK dalam menjalankan tugas dan wewenangnya melaksanakan tiga jenis pemeriksaan yang terdiri atas pemeriksaan keuangan, pemeriksaan kinerja, atau pemeriksaan dengan tujuan tertentu. Pasal 34 ayat (1) UU BPK mengatur bahwa BPK dalam menjalankan tugas dan wewenangnya dibantu oleh Pelaksana BPK.

Hasil penelitian menunjukkan bahwa BPK belum sepenuhnya menyelaraskan ketentuan terkait pelimpahan kewenangan sesuai UU Administrasi Pemerintahan, hal ini terlihat dari pengaturan pada SPKN, Organisasi Tata Kerja Pelaksana BPK, dan PMP yang memberikan pengaturan yang belum sepenuhnya selaras dengan UU Administrasi Pemerintahan terkait pelimpahan kewenangan, khususnya dalam melaksanakan kewenangan 
pada tahap perencanaan pemeriksaan, yaitu penandatanganan Surat Tugas Pemeriksaan, dan tahap pelaporan pemeriksaan, yaitu penandatanganan LHP dan Surat Keluar atas LHP dalam rangka penyampaian ke pimpinan entitas pemeriksaan.

Model pelimpahan kewenangan dari BPK kepada Pelaksana BPK, dan tenaga pemeriksa dan tenaga ahli di luar BPK dalam pelaksanaan tugas pemeriksaan pengelolaan dan tanggung jawab keuangan negara adalah mandat tugas pemeriksaan secara komprehensif, sehingga Pelaksana BPK, dan tenaga pemeriksa dan tenaga ahli di luar BPK melakukan tugas pemeriksaan untuk dan atas nama BPK. Penandatanganan Surat Tugas Pemeriksaan, LHP, dan Surat Keluar atas LHP yang dilakukan oleh penerima mandat harus sesuai ketentuan Pasal 14 ayat (4) UU Administrasi Pemerintahan, sehingga tanggung jawab dan tanggung gugat terhadap proses pemeriksaan terdapat di BPK.

\section{DAFTAR PUSTAKA}

Adrian, A. (2013). Pengaruh Skeptisme Profesional, Etika, Pengalaman, dan Keahlian Audit Terhadap Ketepatan Pemberian Opini Oleh Auditor (Studi Empiris pada BPK RI Perwakilan Provinsi Riau). Jurnal Akuntansi, 1(3).

Aferio, F. (2015). Kebebasan dan Kemandirian Badan Pemeriksa Keuangan dalam Pengawasan Penggunaan Keuangan Negara Berdasarkan Undang-Undang Dasar Negara Republik Indonesia Tahun 1945. Jurnal Online Mahasiswa Fakultas Hukum Universitas Riau, 2(2), 15.

Akbar, B. (2012). Sistem Pengawasan Keuangan Negara di Indonesia. Pusat Kajian Keuangan Negara.

Anggoro, C. (2018). Kewenangan Pemeriksaan Badan Pemeriksa Keuangan atas Badan Usaha Milik Negara. Varia Justicia, 14(1), 40-50.

Ariyanto, D., \& Jati, A. M. (2010). Pengaruh Independensi, Kompetensi, dan Sensitivitas Etika Profesi Terhadap Produktivitas Kerja Auditor Eksternal: Studi Kasus pada Auditor Perwakilan BPK RI Provinsi Bali). Jurnal Ilmiah Akuntansi dan Bisnis, 5(2).

Astuti, D. D., \& Sa'adah, N. (2019). Pelimpahan Kewenangan BPK kepada Perwakilan BPK dalam Pemeriksaan di Daerah. Jurnal Pembangunan Hukum Indonesia, 1(1), 52-63.

Beetham, D. (2018). Max Weber and the Theory of Modern Politics. John Wiley \& Sons.

Bromley, D. W. (1990). The ideology of efficiency: Searching for a theory of policy analysis. Journal of Environmental Economics and Management, 19(1), 86-107.

Fahrojih, I. (2016). Pengawasan Keuangan Negara: Pemeriksaan Keuangan Negara melalui Auditor Internal dan Eksternal serta DPR. Intrans Publishing.

Grandy, C. (2009). The Efficient Public Administrator: Pareto and a Well-Rounded Approach to Public Administration. Public Administration Review, 69(6), 1115-1123.

Jackson, M. C. (2007). Systems Approaches to Management. Springer Science \& Business Media.

Juanda. (2008). Hukum Pemerintahan Daerah. Bandung: Alumni.

Keping, Y. (2018). Governance and Good Governance: A New Framework for Political Analysis. Fudan Journal of the Humanities and Social Sciences, 11(1), 1-8. 
Koontz, H., \& Weihrich, H. (2008). Essentials of Management: An International Perspective (7 ed.). Tata McGraw Hill.

Kusnardi, M., \& Saragih, B. R. (1994). Susunan Pembagian Kekuasaan Menurut Sistem Undang-Undang Dasar 1945. Jakarta: Gramedia Pustaka Utama.

McMahon, C. (2017). Authority and Democracy: A General Theory of Government and Management. Princeton University Press.

Mening, E. J. (2016). Analisis Kepastian Hukum Kewenangan Badan Pemeriksa Keuangan (BPK) Memeriksa Dokumen Rahasia Wajib Pajak Sebagai Bagian Pemeriksaan Pengelolaan dan Tanggungjawab Keuangan Negara [Universitas Gadjah Mada].

Mulya, A., \& Rani, F. A. (2018). Kewenangan Badan Pemeriksa Keuangan Dalam Fungsi Pemeriksaan Terhadap Laporan Pengelolaan Keuangan Pemerintah Daerah. Jurnal Ilmiah Mahasiswa Bidang Hukum Kenegaraan, 2(4), 700-708.

Paputungan, M. H. (2017). Diskursus Kewenangan Audit BPK Terhadap Keuangan BUMN (Perseroan) Pasca Putusan MK Nomor 62/PUU-XI/2013. Mimbar Hukum - Fakultas Hukum Universitas Gadjah Mada, 29(3), 430-444.

Raba', M. R. (2017). Peran Badan Pemeriksa Keuangan (BPK) dalam Melakukan Pemeriksaan Terhadap Pengelolaan Keuangan Negara untuk Mewujudkan Pemerintahan yang Baik Menurut UU No. 15 Tahun 2006. LEX CRIMEN, 6(3), 152160.

Safkaur, O., Afiah, N. N., Poulus, S., \& Dahlan, M. (2019). The Effect of Quality Financial Reporting on Good Governance. International Journal of Economics and Financial Issues; Mersin, 9(3), 277-286.

Sebele, N. (2013). The relationship between government policy and management practices at further education and training colleges. International Journal of Vocational and Technical Education, 5(4), 54-63.

Shoemaker, P. J., Tankard, J. W., \& Lasorsa, D. L. (2003). How to Build Social Science Theories (1st edition). SAGE Publications.

Stoner, J. F., Freeman, R. E., \& Gilbert, D. R. (1994). Management (6th edition). Pearson.

Suzumura, K. (1981). On pareto-efficiency and the no-envy concept of equity. Journal of Economic Theory, 25(3), 367-379. 